\title{
The development of a talent management framework for the private sector
}

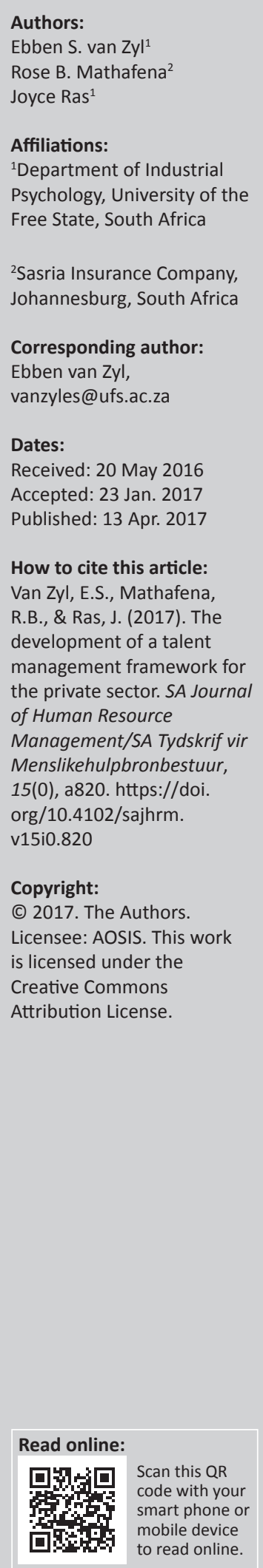

Orientation: Talent management is a strategic priority especially for profit-generating organisations in the private sector. Limited research has been conducted on the theoretical development of talent management. The need for talent management is also triggered by a need to align and integrate people management practices with those of the organisation in order to achieve strategic execution and operational excellence.

Research purpose: The primary aim of the study was to develop a talent management framework for the private sector. The research proposed to conduct an in-depth exploration of talent management practices in key and leading organisations already in the mature stages of talent management implementation in South Africa.

Motivation of the study: There is a need for the development of best practices in talent management - where talent management strategy is designed to deliver corporate and human resource management strategies. The formal talent management initiative would be linked to the human resources management function and will flow vertically from the corporate strategy-making process.

Research approach, design and method: The modernist qualitative research approach was applied to the study. Data were collected through semi-structured interviews (18 persons were interviewed in total). Analytical induction method was instrumental in facilitating the overall data analysis, while constructivist grounded theory assisted with the operationalisation of the data analysis.

Main findings: The study has mapped out key dimensions which are essential for the implementation of talent management. The dimensions of talent management are attraction, sourcing and recruitment, deployment and transitioning, growth and development, performance management, talent reviews, rewarding and recognising, engagement and retention. With each of the above-mentioned dimensions, the activities that are to be carried out to achieve the outcome of each dimension are specified.

Practical and managerial implications: Role clarifications pertaining to talent management responsibilities and accountabilities are still unclear in most instances. Early identification of key role players and articulation of duties will lead to ownership and clear accountabilities for the successful implementation of talent management.

Contribution/value add: The study brought to light critical factors for organisations in the private sector to consider for the successful implementation of an integrated, holistic and comprehensive talent management framework. The proposed framework guides talent management practices within companies in the private sector by highlighting activities to be carried out to achieve outcomes per talent management dimension.

\section{Introduction}

\section{Key focus of the study}

This study focuses on the development of a talent management framework for the private sector. There seems to be a lack of a uniform theoretical talent management framework in the private sector, which can be used as a guideline to drive talent management.

\section{Background}

Collings and Mellahi (2009) asserted that since a group of McKinsey consultants coined the phrase 'war for talent' in 1997, the topic of talent management has received a remarkable degree of practitioner and academic interest. This relatively recent emphasis on talent management 
represents a paradigm shift from more traditional human resource to strategic talent management, which according to Silzer and Dowell (2009) is driven by corporate strategy, incorporated with other processes, managed as a core business practice and deep-seated as a talent mindset. The Chartered Institute of Personnel and Development (2006) further views excellent and best practice level of talent management as a strategy designed to deliver corporate and human resource management strategies. Often there is a formal talent management initiative linked to the human resources management function and flowing vertically from the corporate strategy-making process.

According to Powell and Lubitsh (2007), talent management has moved rapidly up the corporate agenda in recent years, and this is evident in the amount of research papers published over the last decade (e.g. Ashton \& Morton, 2005; Bersin, 2006; Chikumbi, 2011; Church, Rotolo, Ginther \& Levine, 2015; Collings, 2014; Festing \& Shafer, 2014; Nijs, GallardoGallardo, Dries \& Sels, 2014; Meyer, 2005; Odierno, 2015; Prinsloo, 2012). Egerova (2014) is of the opinion that the increasing attention to talent is affected by factors including globalisation, knowledge-based competition, changing the world of work as well as new forms of organisations and demographic changes.

Despite the growing popularity of talent management and over a decade of debate and hype, the concept of talent management remains unclear (Collings \& Mellahi, 2009; Festing \& Schafer, 2014; Nijs et al. 2014). Furthermore, the current state of talent management literature is exacerbated by the fact that in addition to ambiguities around the definition of the concept, there is also alarmingly limited theoretical development in the area as highlighted in the research conducted by Arris, Cascio and Paauwe (2013). Consequently, even though business and consulting firms in the private sector have been driving talent management as a strategic priority, there seems to be an overall lack of theoretical frameworks in the academic field.

Overall, there also seems to be a lack of linkage between talent management practices and the broader human resource systems (Ntonga, 2007), as well as an absence of clear succession planning, skills audits and organisational culture driving talent management (Chikumbi, 2011).

This study attempted to bring to light critical factors which must be taken into account to ensure that organisations can achieve successful implementation of an integrated, holistic and comprehensive talent management framework. The framework will strive to guide talent management practices within companies in the private sector, and also improve and advance the maturity of talent management application.

\section{Purpose}

The primary aim of the study was to develop a talent management framework for the private sector. The secondary aim of this study was to conduct a modernist qualitative research study in order to explore and gain in-depth knowledge on talent management and what it entails.

More specifically, the study aimed to:

- bring to light the understanding of the concept of talent management through moving towards a clear language of defining talent management as well as the content thereof

- apply qualitative research and the use of analytic induction as an overall data analysis strategy, while using constructionist grounded theory to operationalise the data analysis, thus elucidating how these approaches can be used in talent management studies

- inform human resource practitioners and business managers on how to plan, implement and evaluate talent management in their business in the most comprehensive, systematic, integrated, strategically driven and flexible manner while realising the benefits for the business.

\section{Contribution to the field}

The study will contribute theoretically and practically to the operation of businesses in the private sector. From a theoretical perspective, the concept of talent management is illuminated, and knowledge in the field of talent management is extended through the development of a talent management framework. The practical contribution includes access to a well-integrated talent management framework, the purpose of which is to facilitate the implementation and improvement of talent management.

Furthermore, human resource practitioners and talent management specialists will benefit from the developed talent management framework as it will aid and guide the best practice of talent management. The implementation of the best practice of talent management will work only if the planning, implementation, tools, practices, tactics and dimensions of talent management are correctly applied as advised by the research insights.

Lastly, the current status of qualitative research, analytic induction and constructivist grounded theory will be expanded in the areas of talent management and human resource studies in South Africa.

\section{What will follow}

A conceptual overview of talent management is provided below, as well as a discussion on key aspects linked to talent management, followed by a description of the research design and results.

\section{Conceptual overview of talent management}

Meyers and Van Woerkom (2013, p. 23) refer to talent management as 'the systematic utilisation of human resource management (HRM) activities to attract, identify, develop, and retain individuals who are considered to be "talented".' 
Meyer (2005) highlights that the attraction, growth and retention of talent are key factors for modern organisations that are knowledge driven. To be known as an employer of choice is considered a key organisational goal with direct benefits.

Chikumbi (2011) in a quantitative study investigating talent management and staff retention at the Bank of Zambia reveals that successful management of talent and employee retention leads to the organisation attaining a competitive edge. The study highlights that improved talent management leads to increased productivity, motivated staff, innovation and high employee contribution towards the organisation.

Odierno (2015) states that talent management offers real and tangible benefits of reducing recruitment costs, effective knowledge transfer, realisation of business strategy, delivery of cutting-edge services and products and the creation of a competitive advantage, in spite of the many challenges that organisations face in order to be sustainable. Ashton and Morton (2005) argue that good talent management is of strategic importance and can differentiate an organisation when it becomes a core competence, and its talent significantly improves strategic execution and operational excellence.

Prinsloo (2012), in her study of talent management and the psychological contract, provides evidence that management can use talent management practices to strengthen the psychological contract, leading to lower turnover, improved motivation productivity and loyalty. Bersin (2006) asserts that entry into the new era of talent management was because of more challenging people-related issues requiring tighter integration between human resource silos and the business. As an organisation strives to meet business goals, it must ensure that it has continuous and integrated processes for recruiting, training, managing, supporting and remunerating these people, and thus the need for talent management.

\section{Key aspects linked to talent management}

The next section will highlight the key aspects that could be linked to talent management (as identified out of the literature).

\section{Employer of choice, best company to work for and employer brand}

The branding of a company as 'employer of choice' and 'best company to work for' is important in supporting talent management initiatives, as the company will have a reputation of being a great place to work for (Gatherer \& Craig, 2010). Li and Bryan (2010) emphasised that in the quest to become employer of choice, organisations need to create and sustain a workplace which brings a deeper understanding of elements contributing to the workplace climate.

\section{Employee engagement}

Tucker and Williams (2011) believe that various actions taken at different points of the talent management cycle boost employee engagement. Effron and Ort (2010) suggested that most talent management practitioners believe that increasing engagement achieves the business objectives of improving key financial and operational results. Furthermore, Caplan (2011) claims a link between talent management and employee engagement in that talent management significantly impacts employee engagement, as they have common and similar indicators such as employee development, utilisation of employees' capability and so on.

\section{Employee value proposition}

Collings (2014) asserted that employees who create and contribute value to the organisation should get value back from their organisation in the form of employee value proposition (Employee Value Proposition). Bell (2005) views the Employee Value Proposition as a key differentiator of success for organisations competing to recruit, develop, inspire and retain talented people. The best practice is to develop a convincing, credible and competitive Employee Value Proposition which can be responsive to the expectations of talent.

\section{Organisational culture and core values (healthy climate)}

DeLong and Trautman (2011) highlighted that organisational culture can be used to drive talent management, as culture is a major factor in determining the success of projects and programmes. You can have the most elegant leadership development plans and talent management initiatives imaginable, but if they are not supported by company cultural practices, norms, values and assumptions, then these programmes will have little impact. Pellant (2011) perceived culture as the way people behave, as culture is in the behaviour that is permitted and in the attitudes that are allowed. In organisations, culture exists in how people treat each other, customers, suppliers and other stakeholders. Therefore, a set of behaviours and actions which encourages and supports talent management has to be cultivated and promoted. Haid, Sims, Schroeder-Saulnier and Wang (2010) are of the view that the shared assumptions and values of how to behave and carry out work activities in the organisation must be aligned with the desired culture to achieve business objectives and also support talent and people management practices.

\section{Alignment of business strategy to talent management}

Hatum (2010) emphasised the importance of aligning talent management strategies with those of the overall organisational strategy. Johnson, Scholes and Whittington (2011) view strategy as the direction and scope of an organisation over the long term, which achieves advantage in the changing environment through its configuration of resources and competencies with the aim of fulfilling stakeholder expectations. The firm needs to have the ability to deliver a holistic talent management strategy which supports the 
overall business strategy, and in turn allows the firm to perform strongly in the market. According to Johnson et al. (2011), this means that the firm has one coherent plan that brings all areas together in a consistent manner. Internal alignment in areas of information technology, communication, finance, legal, marketing, human resources and talent management is critical in sending clear, reliable and consistent messages to employees.

\section{Career life stages and phases}

Knowledge of the various career life stages and phases is important, particularly in relation to talent management processes as it creates an understanding of the particular needs and preferences of the talent, for example, what learning programmes, reward systems, engagement, branding and attraction tactics can be employed for the talented at various career and life stages (Cron \& Slocum, 1989). Hess and Jepsen (2009) acknowledged that there are age-related differences related to differences in individual needs based on their career stage. The specific needs for career development, promotions and success of each career stage need to be identified. In the early stages, employees are focused on achievement, getting ahead, personal growth, self-esteem and competence as these are key priorities (Hess \& Jepsen, 2009).

\section{Generational theory and multiple generational workforce}

Boshard and Louw (2011) projected that half of the retiring baby boomers in senior management positions would widen the gap of talent availability and supply, which would result in most companies turning to Generation $X$ and $\mathrm{Y}$ employees in search of talent and skills. The white paper released by the United Nations Secretariat Headquarters (Boshard \& Louw, 2011) strongly proposed that managing a multigenerational workforce is a challenging art in itself and that understanding the differences between the generations is fundamental in building a successful multigenerational workplace. Organisations must seek to optimise the talents of all age groups, while reconciling differences in the workplace, educating and allowing employees to utilise this diversity for individuals and for organisational advantage.

\section{Stratified systems theory, levels of work and complexity}

Talent management goes hand in hand with placing high potential employees on highly critical work projects, and also progressively growing and promoting people. Careful thought has to be placed on the complexity of the role against a set of skills and competence possessed by the employee at a particular career and life stage (Greene, 2010). Stratified systems theory and levels of work and complexity theory help to shed light on identifying the required skills for each complex role (Greene, 2010).

\section{Ethics in talent management}

Rose (2007) views ethics as a key branch of philosophy concerned with analysing what is right and wrong in people's behaviour or conduct. Ethics and morality are terms that are often used interchangeably in discussions of good and evil. Talent management as a practice needs to incorporate a moral and ethical stance, while adding value to the organisation. A high degree of standards, credibility, fairness, justice, taking responsibility and professionalism have to be exhibited in all activities related to talent management (Hess \& Jepsen, 2009).

\section{Research design Research approach}

The qualitative research approach was selected because of the nature of the research process being flexible and emergent. Leedy and Ormrod (2010) indicate that qualitative research seeks a better understanding of complex situations and is sometimes exploratory in nature. A modernist qualitative research method was utilised in order to explore and gain indepth knowledge on talent management and what it entails. With the study, the researcher hopes to further examine effective and leading best practices and challenges in the implementation process of talent management. Analytic induction and constructivist grounded theory was applied to analyse the data.

\section{Case selection strategy}

A multiple site case study design was adopted as the research was conducted in two different companies, mainly for the purposes of comparison and verification and to observe similarities and characteristics in the data sets collected (Moore, Lapan \& Quartaroli, 2012). According to Bromley (1990), case study research is a systematic inquiry into an event or a set of related events which aims to describe and explain the phenomenon of interest. Leedy and Ormrod (2010) explain that in other instances researchers study two or more cases, often cases that differ in certain key ways in order to make comparisons, build theory or propose generalisations. Such studies are called multiple or collective case studies.

\section{Research method Research setting}

The field setting can be described as those companies who are identified as 'Best Employers' and are certified as such because they meet the requirements of being competitive in the areas of human resource management. They are serious about distinguishing themselves amongst industry peers in the critical areas of pay and benefits, training and development, career opportunities, working conditions and company culture. According to the Corporate Research Foundation (2011), widely known as the Corporate Research Foundation Institute, both the companies are listed in the top 10 ranking as best employers in the private sector.

\section{Entrée and the research roles establishment}

Quandt, McDonald, Bell and Arcury (1999) indicated that gaining entry into the research field is quite an intensive process which requires perseverance, persistence and a lot of 
planning and communication skills. Yin (2011) stated that doing research implies interacting with the real world, situations and the people in them. In order to enter and exit research settings, some formality is required, particularly in obtaining the necessary permissions to do the study. In gaining entry to the field, key informants who provided authorisation and permission to conduct the study in the two identified companies provided a list of potential participants for the study. The potential participants were approached through electronic mail to communicate the purpose of the study, and thereafter the interviews were scheduled. The researcher adopted a formal interviewer role, attempting to elicit responses from the interviewees. The researcher used notes, as participants did not feel comfortable with the use of a voice-recording device. The researcher also assumed the role of an observer of the participants, the work environment and of the general company employees.

\section{Sampling}

The purposive non-random or non-probability sampling method was selected for the study. In addition, convenience sampling was used with regard to the unsolicited documents issued to support the interview data. In this type of sampling, the researcher determines the most typical characteristics of the participants that could be included in the sample. Inclusion criteria are created based on the judgement of the researcher and are used to deliberately include specific participants in the study (Botma, Greeff, Mulaudzi \& Wright, 2010). Characteristics essential for membership in the sample were as follows: the participant must be employed in an organisation that clearly practices talent management or must have been exposed to talent management practices as a manager, human resource practitioner or a beneficiary of the talent management programme.

\section{Research participants}

The participants identified for the study were human resource practitioners, management members and beneficiaries of the talent management programmes. The selected organisations are widely and publicly recognised for having effective talent management programmes.

From Company A, nine participants took part in the first round of interviews, of which five were white females, two Indian females, one African female and one African male, all aged between 31 and 55 years, with one exception aged below 30. Four participants from Company B took part in this first round of interviews, of which all were white, two males and two females aged between 36 and 45 . Interviews with participants lasted for 60-90 $\mathrm{min}$.

The second round of interviews (to test the framework and collect additional data) were conducted with one person from Company A, who issued the researcher with seven documents, while from Company B four participants were interviewed. Four of the participants had a degree and had completed postgraduate studies. Four of the participants were already at middle and senior management levels in their careers, while one was at junior management and executive level.

\section{Data collection methods}

To achieve the objectives and aims of the research, the researcher opted to combine a few methods of data collection. Botma et al. (2010) stated that qualitative researchers typically gather multiple forms of data and thus make use of a combination of research methods. The data collection methods refer to interviewing, observations, document collection and field notes. During the first round of the oneon-one interviews, the researcher followed a semi-structured approach of interviewing (at the organisations' premises) in order to ensure that the open-ended questions were aligned with the research questions. This allowed flexibility and additional questions to arise during the interview process. The unstructured, in-depth interview was used during the second round of interviews to verify the initial proposed framework and the initial data analyses and coding of themes. Furthermore, the researcher conducted informal and unstructured observations of the participants, the settings, the environments and how people interacted in the company environment. The unsolicited documents in the form of internal company publications (agendas and minutes of meetings, internal office memos, financial records and annual reports) were issued to the researcher to support the data.

\section{Data recording and storage}

Leedy and Ormrod (2010) suggested that in conducting a productive interview, the researcher needs to record all responses verbatim, whether through the use of handwritten notes, shorthand and tape recordings or via direct capturing onto a computer, especially if it is an unstructured, in-depth interview. Interview data (from conversations, responses and information given by the research participants during the semi-structured interviews) were recorded in a written format. All the handwritten data were transferred and converted into an electronic format through a word processor. Furthermore, precautions were taken to safeguard data through backup on a compact disk, flash drive or a storage device that can be kept in a safe place.

\section{Data analysis}

In the current study, Johnson's (2004) analytical induction procedure was applied, as implemented in Bondas (2006), as well as Charmaz's (2000) constructivist grounded theory for operationalisation of data analysis. Findings of Marshall and Rossman (1995) were incorporated to cover the data testing, validation and verification phase. Analytical induction according to Smelser and Baltes (2001) is a research logic used to collect data, develop analysis and organise the presentation of research findings. Its formal objective is causal explanation, a specification of the individually necessary and jointly sufficient conditions for emergence of some part of social life. A slightly modified approach 
of analytical induction was applied as an overall and overarching data analysis method. Charmaz (2006) defines grounded theory as an inductive, iterative and comparative method geared towards theory construction. Grounded theory served the purpose of operationalisation of the data analysis, more specifically for coding purposes. The analysis process entailed a movement between deductive (theory and literature) and inductive analysis approaches (emergent insights from the data), resulting in the development of the talent management framework. Thomas (2006) views deductive data analysis as set out to test and illuminate consistency with prior assumptions, knowledge and theory.

The initial coding process achieved the clustering of similar data sets, and also the naming of these. Once the initial coding was completed, the researcher then progressed to the focused coding where the dense data were further de-layered into simpler and more specific sub-themes. These sub-themes are substantiated and supported by excerpts from the interview scripts. The focused coding stage resulted in the reduction of the data even further to identify and develop relevant sub-themes.

Theoretical coding consequently led to identification of the interrelatedness and the relationships between the concepts, themes and sub-themes, leading to the development of the talent management framework.

Furthermore, the sense-making of the data which resulted in the initial and proposed talent management framework was supported and influenced by a combination of prior knowledge (deductive) as well as emergent insights (inductive) from the data. Thomas (2006) refers to inductive analysis as a detailed process of reading the data to derive concepts, themes, models and frameworks. Thomas (2006) views deductive data analysis as set out to test and illuminate consistency with prior assumptions, knowledge and theory.

\section{Validation, verification and triangulation of the initial talent management framework}

Following the analytic induction process, the researcher visited Companies A and B to verify, test, triangulate and validate the initially developed framework through unstructured followup interviews with the five participants. The initially proposed talent management framework was electronically mailed to the participants in order for them to advise on whether the framework could be improved, and to indicate the aspects needing improvement. The sixth participant opted not to have an interview but confirmed via electronic mail that the framework and the analysed data constituted a true reflection of what was discussed in the initial round of the interviews conducted. Out of the six participants, two took part in the initial interviews and confirmed and validated the data in comparison to the initially proposed framework. While the other four were not involved in the initial interviews, they could only comment mostly on the comprehensiveness and relevance and could also advise on what concepts should be incorporated into the initially proposed framework to improve it further.
Furthermore, the two companies offered the researcher eight documents in the form of internal publications. The offering of these documents was completely unsolicited. Therefore, the researcher applied initial, focused and theoretical coding principles to analyse the unstructured interviews and the documents.

\section{Ensuring quality of the study}

In conducting the study, the researcher had to ensure the quality of the study in every step of the research, while also adhering to ethical conduct and standards.

For the trustworthiness of the study, the researcher had to ensure that the insights were that of the research participants and not her own. The researcher ensured the correct meaning and wording of what participants shared with her, by writing down and repeating it in the presence of the interviewee. Credibility triangulation was applied through collecting data from the two cases or companies as a basis for comparison. Furthermore, the researcher conducted the second round of interviews at the same companies with a mix of old and new participants. In addition, unsolicited documents were also used as a source of triangulation, verification and validation of the data, as well as for testing the proposed talent management framework.

\section{Results}

To develop a talent management framework for the private sector, the researcher formulated key and central research questions, which were answered by the research participants and are reflected in the themes and sub-themes. The research questions are listed below:

- What are talent and talent management?

- What does the content of talent management entail?

- What are the typical challenges experienced in the implementation of a talent management programme?

- What are effective talent management practices which are working, and why are they working?

- What can be done to improve the effectiveness of talent management programmes?

- What are the leading best practices regarding recruitment, deployment, development, engagement and retention of talent?

- What value does talent management add to the organisation?

- How do individual career life cycles influence the approach to talent management?

- What is the link between diversity management and talent management?

According to Lacey and Luff (2009), the initial coding process entails the beginning of identification of themes and emergent concepts, which will later lead to the engagement of recoding to develop more well-defined categories. Familiarisation with the data by reading and rereading is essential. 
The researcher read through the data to get a general sense of what the participants had said. She then started putting similar ideas together into chunks. The chunks of data were grouped together based on an answer to a particular question, idea or theme. The researcher had found that questions from the semi-structured interviews shaped the formation of the data because similar data sets were clustered around a particular question. The researcher then decided on an initial label, code or descriptive wording to name the chunks of data brought together. She then came up with nine data labels, namely, defining talent and talent management, talent management programme content, information technology and systems, organisational climate and culture, role players in talent management, challenges in talent management, business case for talent management, optimising talent management and career life stages.

\section{Defining talent and talent management}

Table 1 represents excerpts from interviews with all participants on how they defined talent. There seemed to be strong cohesion and consensus about the definition of talent. No conflicting views about the profiling of talent, even between Companies A and B, were noted. The data were further clustered into sub-themes to highlight the important concepts which led to the overall definition of talent.

Table 2 gives a brief definition of talent management as per the participants' data input. The most important view arising from the data is the perception of talent management in the context of the overall employee life cycle (from hiring to exiting).

\section{Talent management programme content}

Table 3 demonstrates the participants' views on what a talent management programme should entail in the best practice environment. The various sub-themes are segmented and supported by ideas and insights from the participants. The content of talent management and sub-themes are critical in the ultimate formulation of talent management dimensions or elements.

\section{TABLE 1: Defining talent.}

\begin{tabular}{ll}
\hline Theme 1: Talent & Excerpts from interviews \\
\hline Talent & $\begin{array}{l}\text { Talent does work for our clients as we sell time, knowledge, } \\
\text { service } \\
\text { People are not machines on a production line } \\
\text { Time and money must be invested in people to build } \\
\text { knowledge and experience } \\
\text { Talent Management brings profit } \\
\text { Talent - best profile - culture, skills, academic } \\
\text { Cream of the crop } \\
\text { They are top 10\% in the organisation (A7) } \\
\text { Talent is key to people in business operations (A8) } \\
\text { This excludes poor performers } \\
\text { May be individual contributor (specialist or manager) (B1) } \\
\text { Talented are defined as having strength and passion - are } \\
\text { excellent people (B2) }\end{array}$ \\
\hline
\end{tabular}

\section{Information technology and systems}

In Table 4, the participants and sources indicated how information technology and systems can assist and support the talent management processes and implementation. Having systems and processes will not necessarily make the practice of talent management successful but will enable the effectiveness of the process. These systems are mainly for reporting and data management purposes.

\section{Organisational climate and culture}

In this theme (see Table 5), the participants emphasised the importance of the overall culture, values and behaviour at work, which set the mood or temperature of the workplace environment. The point that is driven is that it is important to create a healthy and humane work environment where people can look forward to coming to work.

\section{Role players in talent management}

In Table 6, the participants and sources highlighted the importance of role clarity in the implementation of talent management. Clear accountabilities and deliverables need to be set, as to who does what, and who is responsible for what with regard to talent management.

\section{Challenges in talent management}

Participants with exposure to talent management practices have reflected on the potential and the real challenges that come with the implementation of talent management (see Table 7). Issues that could potentially derail talent management implementation are flagged, thus creating awareness to help prevent future pitfalls. Much as the companies strive for people management best practices, certain areas still need improvement.

TABLE 2: Defining talent management.

\begin{tabular}{ll}
\hline Theme 2: Talent management & Excerpts from interviews \\
\hline Talent management & Talent Management is a philosophy of how to \\
manage talented people & Programme is critical \\
It is about attracting and managing the best out \\
of people \\
Need to keep them engaged, it is challenging to \\
retain them \\
Talent Management is to identify current talent \\
and future talent \\
Support them in growing and being happy \\
Ensure engagement based on individual needs, \\
constant learning \\
Talent Management is everything from attracting, \\
selecting, recruiting, retaining, exiting and life \\
cycle of the employee with the company \\
Talent Management - learning, \\
acknowledgement, career pathing detailed with \\
timelines, counselling, open communication, \\
performance evaluation \\
Talent Management - process of acknowledging, \\
recognising, and investing in people strengths \\
Ensuring derived benefit from the programme of \\
training and developing skills \\
Opportunity to gain skills and experience \\
Be exposed to key leadership in the process \\
\hline
\end{tabular}




\section{Business case for talent management}

In this section (see Table 8), talent management is not viewed in isolation from the business operations. The importance and necessity of talent management is shared by the participant as a business imperative necessary for continuity and success of the business. The value add of

TABLE 3: Talent management programme content.

\begin{tabular}{|c|c|}
\hline $\begin{array}{l}\text { Theme 3: Talent } \\
\text { management programme }\end{array}$ & Excerpts from interviews \\
\hline \multirow{29}{*}{$\begin{array}{l}\text { Best practices of } \\
\text { programme content }\end{array}$} & Tell talented people the truth \\
\hline & Accommodating female gender to work flexibly \\
\hline & $\begin{array}{l}\text { Recruit through headhunting and graduate } \\
\text { recruitment }\end{array}$ \\
\hline & Senior leadership must buy in to the programme \\
\hline & $\begin{array}{l}\text { Senior leadership must be part of the learning and } \\
\text { development }\end{array}$ \\
\hline & Having good managers is key to retention \\
\hline & $\begin{array}{l}\text { Managers play a critical role in training people to be } \\
\text { competent }\end{array}$ \\
\hline & Communication is critical in influencing and retention \\
\hline & Communication between leadership and employees \\
\hline & Adjust and be flexible about the programme \\
\hline & Add fun to the equation \\
\hline & Treat employees as clients \\
\hline & Sincerity of communication is critical \\
\hline & Honest and open feedback is good for people \\
\hline & $\begin{array}{l}\text { The programme for high potentials in various steps of } \\
\text { progression }\end{array}$ \\
\hline & $\begin{array}{l}\text { There are calibration sessions, on round tables to } \\
\text { review talent }\end{array}$ \\
\hline & $\begin{array}{l}\text { Human resource management and line management } \\
\text { justify talent ratings }\end{array}$ \\
\hline & $\begin{array}{l}\text { Ratings are questioned and there are participative, } \\
\text { robust discussions }\end{array}$ \\
\hline & $\begin{array}{l}\text { Talent review process ensures evaluation, checking } \\
\text { and consistency of the programme }\end{array}$ \\
\hline & Learn more about diversity and cultural differences \\
\hline & $\begin{array}{l}\text { Have a clear criteria for identifying talent with no } \\
\text { subjectivity }\end{array}$ \\
\hline & $\begin{array}{l}\text { As a benefit, there is an employee assistance } \\
\text { programme - they arrange service providers (booking } \\
\text { a holiday, tutor children after school, baby sitters) }\end{array}$ \\
\hline & There is a gym in the building \\
\hline & $\begin{array}{l}\text { There is a counselling helpline for personal and } \\
\text { emotional support of employees }\end{array}$ \\
\hline & $\begin{array}{l}\text { A prestigious brand makes a difference - people want } \\
\text { to join the organisation }\end{array}$ \\
\hline & The programme of managing high potentials is excellent \\
\hline & It is part of talent acquisition \\
\hline & $\begin{array}{l}\text { The programme has to incorporate diversity to have } \\
\text { right mix of people }\end{array}$ \\
\hline & Grading process - allows broad banding \\
\hline \multicolumn{2}{|c|}{ Sub-theme: Best practices of programme content } \\
\hline \multirow[t]{9}{*}{$\begin{array}{l}\text { Learning, development and } \\
\text { competencies }\end{array}$} & $\begin{array}{l}\text { We train graduates in accounting and tax fields for } \\
3 \text { years }\end{array}$ \\
\hline & Formal training, study funding, study leave generous \\
\hline & They learn emotional intelligence skills \\
\hline & $\begin{array}{l}\text { Manager trains for special and technical skills to early } \\
\text { career employees }\end{array}$ \\
\hline & Training - structure courses per job - compulsory \\
\hline & Global training, in-house and external training \\
\hline & $\begin{array}{l}\text { Leadership development, technical and soft skills } \\
\text { (Emotional Intelligence) training }\end{array}$ \\
\hline & $\begin{array}{l}\text { Training - learning, experience, and knowledge } \\
\text { coaching needed for career development }\end{array}$ \\
\hline & General learning experiences \\
\hline
\end{tabular}

talent management is highlighted below in the sub-themes that arose.

\section{Optimising talent management}

The participants shared their views on how to further enhance and improve current talent management practices

TABLE 3 (Continues...): Talent management programme content.

\begin{tabular}{|c|c|}
\hline Theme 3: Talent & Excerpts from interviews \\
\hline & Business schools' short courses \\
\hline & $\begin{array}{l}\text { Providing blended learning - formal learning, } \\
\text { on-the-job training and coaching }\end{array}$ \\
\hline & Talent must develop skills that are holistic \\
\hline & Management development \\
\hline & Graduate development \\
\hline \multirow[t]{9}{*}{ Performance management } & $\begin{array}{l}\text { Employees receive feedback on performance after } \\
\text { every project }\end{array}$ \\
\hline & $\begin{array}{l}\text { Non-performer on performance improvement } \\
\text { programme }\end{array}$ \\
\hline & Well-structured performance management system \\
\hline & $\begin{array}{l}\text { Robust performance management - what is expected, } \\
\text { what they must achieve, job specifications aligned to } \\
\text { business goals, annual plans and strategic link }\end{array}$ \\
\hline & Managers evaluate performance \\
\hline & Performance management \\
\hline & $\begin{array}{l}\text { Give performance feedback and share areas needing } \\
\text { development }\end{array}$ \\
\hline & Create a mechanism to enhance performance \\
\hline & Inspire people towards greatness \\
\hline \multirow[t]{11}{*}{$\begin{array}{l}\text { Placement, deployment and } \\
\text { recruitment }\end{array}$} & $\begin{array}{l}\text { Deployment - place people in right projects matching } \\
\text { their skills and learning needs }\end{array}$ \\
\hline & $\begin{array}{l}\text { In recruiting and deploying, ensure experience, } \\
\text { culture, values, diversity, knowledge fit }\end{array}$ \\
\hline & $\begin{array}{l}\text { Use a matrix to determine strength in competence } \\
\text { and values }\end{array}$ \\
\hline & Deployment - job description, global competencies \\
\hline & Deployment - matching of strength of ability \\
\hline & $\begin{array}{l}\text { Analyse their capabilities - competencies - } \\
\text { assessments }\end{array}$ \\
\hline & Teaming dynamics to facilitate learning \\
\hline & $\begin{array}{l}\text { Talent Management - strength-based recruiting, } \\
\text { deploying and engaging }\end{array}$ \\
\hline & $\begin{array}{l}\text { Find out people's strengths and allow them to } \\
\text { capitalise on them }\end{array}$ \\
\hline & $\begin{array}{l}\text { Use people where they are really good and } \\
\text { passionate }\end{array}$ \\
\hline & $\begin{array}{l}\text { Use a strength finder tool - influence, relationships } \\
\text { and execution }\end{array}$ \\
\hline \multirow[t]{5}{*}{ Orientation } & $\begin{array}{l}\text { Induction/on-boarding/orientation - structured, high } \\
\text { level, formalised content }\end{array}$ \\
\hline & $\begin{array}{l}\text { On-boarding - go to person/coach, walk and talk } \\
\text { partner }\end{array}$ \\
\hline & Orientation and induction \\
\hline & $\begin{array}{l}\text { A buddy system when on-boarding } \\
\text { Induct them as brand ambassadors }\end{array}$ \\
\hline & Intensive and structured induction \\
\hline \multirow[t]{9}{*}{ Engagement and retaining } & $\begin{array}{l}\text { Sense of job purpose - importance and how one adds } \\
\text { value to bigger picture }\end{array}$ \\
\hline & Contribution and purpose-driven job - meaningful work \\
\hline & Offer value proposition - career, high performance \\
\hline & Networking events - with guest speakers \\
\hline & Exposure to senior leadership \\
\hline & Attending professional conferences \\
\hline & Conversation breakfast \\
\hline & Internal and external functions \\
\hline & Communication \\
\hline
\end{tabular}


TABLE 4: Information technology and systems. Theme 4: Information technology and systems Excerpts from interviews and sources

Theme: Information technology and systems

Rate of return on investing in talent is critical - analytics

Talent management processes are driven by technology (sources)

Sub-theme: Information technology and systems

E-recruitment

E-learning

Analytics - forecasting people's needs and profiling of talent pool (skills)

Tracking of training, competency development and assessments kept on the system

Learning circles

E-learning is utilised for compliance and compulsory training

Learning assessments are tracked online for progress

A scorecard is kept for training - indicating performance (all been trained)

Online coaching and mentoring process

E-performance

E-succession planning

Remuneration

Social networking

Data analytics and reporting

Performance assessments are completed on the Human Resource Management system (sources)

Software utilised to record succession plans and progress

Capture results on money spent on talent (salaries)

Online service supporting coaching - virtual coaching

Reporting must be compiled to reflect statistics on attrition and diversity balance

Retention statistics are critical - to assess if we recruit correctly

Measuring business benefits related to Talent Management is critical

Talent data

Systems assist management to view data on workforce profiling, demographics, gender, talent pools (sources)

Measure what is working and what is not working

The data is reported on an Human Resource Management-integrated system

There are updated people profiles and analytics

There is high potential people reporting

TABLE 5: Organisational climate and culture.

\section{Theme 5: Organisational climate}

Organisational climate (general)

Sub-theme: Organisational climate Team-based

Communication

\section{Excerpts from interviews and sources}

No private offices - only open plan offices - creating a socially, open and vibrant climate

Happy - not go to work and be miserable

Happy - know I am needed and appreciated

Happy - relationships at work

Not a number - but a person - (humanness at work)

Happy - caring for people culture

Happy with person's ability and individuality

Organisational climate is monitored through climate surveys

Dimensions are work group relations, teaming, management engagement

Job satisfaction

Feedback on management

Policy and structure (sources)

Fair remuneration and benefits

Motivation and engagement

Open plan offices to encourage openness and teaming

High technology environment

Very relaxed style

Technology is the key driver (sources)

A prestigious brand makes a difference - people want to join the organisation

Food subsidies - with the canteen

Secure and beautiful environment

Opportunity to travel overseas

Technology that is top edge

Technology driven

Flat organisation, people work on team-based projects

Flat structure - team-based work projects

Open plan office - social and open communication

We work in teams - teaming dynamics are critical

Team and building relations

We work together to achieve

Knowledge sharing is a culture mostly in a team context (A1)

Innovative communication - plasma screen (A3)

People relate informally - communication

Long hours, electronic mail is mode of communication 
TABLE 5 (Continues...): Organisational climate and culture.

\begin{tabular}{|c|c|}
\hline Theme 5: Organisational climate & Excerpts from interviews and sources \\
\hline \multirow[t]{12}{*}{ Leadership ethics } & No micro management \\
\hline & Honesty and transparency about performance and rewards \\
\hline & Line manager - equipped with interpersonal skills \\
\hline & Not political - unlike competitors \\
\hline & Not hierarchical \\
\hline & Leaders are visible and accessible \\
\hline & Manager sits with teams in open plan offices - no private offices \\
\hline & Not hierarchical and hung up on titles \\
\hline & Leadership - approachable \\
\hline & Quality of supervision \\
\hline & No micro management (twice) \\
\hline & Management style is open and straight talk \\
\hline \multirow[t]{8}{*}{ Diversity and inclusiveness } & Managers are required to recruit diverse people \\
\hline & Make diverse people feel comfortable and motivated \\
\hline & Diversity - awareness created about other religions, cultures and practices \\
\hline & Diversity - canteen caters for various dietary requirements \\
\hline & Diversity and inclusiveness culture \\
\hline & There is no gender bias in the environment \\
\hline & A climate that is open to diversity of both race and gender is critical \\
\hline & Diversity is a culture (multinational) \\
\hline \multirow[t]{5}{*}{ Wellness } & $\begin{array}{l}\text { Wellness counselling - talented experience stress, personal and social problems, conflict, work issues. We use an anonymous employee } \\
\text { assistance programme }\end{array}$ \\
\hline & Wellness - help with pressure management, as they work long hours (Employee Assistance Programme) \\
\hline & $\begin{array}{l}\text { Work-life balance is encouraged - programme to coach people to integrate work } \\
\text { Better }\end{array}$ \\
\hline & Employee assistance to enable - counselling, conflict and family management \\
\hline & The organisation pays for employee counselling of up to six sessions \\
\hline \multirow[t]{4}{*}{ Flexible work hours } & Flexible work - I have kids and family, raised them, and a career \\
\hline & Accommodating personal wholeness - social and career - play golf \\
\hline & Results driven not being present at work - flexibility - client not inconvenienced \\
\hline & Flexible work arrangements are critical - as long as one performs \\
\hline \multirow[t]{8}{*}{ High performance culture } & After every project employees are evaluated and receive performance feedback (communication) \\
\hline & Career oriented and high performance culture \\
\hline & Pay, productivity, strategy, rules \\
\hline & Enablement to do the job \\
\hline & Empowerment, technology and performance \\
\hline & Culture is innovative and strongly performance driven \\
\hline & It is an output-driven environment \\
\hline & There is a high performance culture \\
\hline \multirow[t]{6}{*}{ Learning and development culture } & We recognise people for learning and gaining knowledge (sources) \\
\hline & A culture of learning, helping people to achieve \\
\hline & Knowledge management - there is rich experience, knowledge, expertise \\
\hline & Career development opportunities \\
\hline & There are mainly knowledge workers (Information Technology specialists and sales) \\
\hline & Being surrounded by knowledge experts in the field \\
\hline \multirow[t]{6}{*}{ Values } & Talented undergo life circumstance changes (social/emotional) - we have an employee assistance programme \\
\hline & Team relations - integrity, honesty, ethics are recognised \\
\hline & There is trust and respect for people in the culture (sources) \\
\hline & Personal crises accommodated \\
\hline & Culture - right values, career driven, people who like people \\
\hline & Respect is a core value \\
\hline
\end{tabular}

TABLE 6: Role players in talent management.

\begin{tabular}{ll}
\hline Theme 6: Role players & Excerpts from interviews and sources \\
\hline Role players (general) & $\begin{array}{l}\text { Management and Human Resource Management must be seen to build trust } \\
\text { Managers and Human Resource Management play a role of communication with talented } \\
\text { Human Resource Management and line management justify talent ratings }\end{array}$ \\
$\begin{array}{l}\text { Sub-theme: Role players } \\
\text { Line management }\end{array}$ & $\begin{array}{l}\text { We rely on managers to coach, transfer knowledge and skills } \\
\text { Managers are appraised on people leadership, motivating teams, coaching ability, delegating and knowledge sharing } \\
\text { Managers ensure performance objectives are aligned to strategy }\end{array}$ \\
\hline
\end{tabular}


TABLE 6 (Continues...): Role players in talent management.

\begin{tabular}{|c|c|}
\hline Theme 6: Role players & Excerpts from interviews and sources \\
\hline & Line managers know their people and acknowledge them \\
\hline & Line manager - interested in employee career development \\
\hline & Line manager to focus on people and business results (sources) \\
\hline & We rely on line managers to implement Talent Management \\
\hline & Line managers are professional experts and have technical knowledge \\
\hline & Line managers are required to meet regularly with high potential people \\
\hline & Line managers to have career conversations \\
\hline & Compile detailed action plans of developing people \\
\hline & Line managers play a role in enabling talent to succeed \\
\hline & Line management need to commit to the programme \\
\hline & Line managers need to facilitate and support Talent Management programmes \\
\hline & Management to empower people to do more \\
\hline & Line manager to reward and recognise employees' achievements \\
\hline \multirow[t]{5}{*}{ Executives } & Directors have regular career sessions with key talent (sources) \\
\hline & Leadership - to invest time, experience, giving and coaching \\
\hline & Executives must be people's people, one-on-ones \\
\hline & Director buy in to Talent Management - the top must understand importance of Talent Management \\
\hline & Executive can assist middle managers - experience training, coaching, support formal training to prepare for future roles \\
\hline \multirow[t]{8}{*}{ Human resource } & Human resource Management trains all managers as counsellors - be able to coach, communicate and teach \\
\hline & Human Resource Management to encourage people to use employee assistance programme \\
\hline & Human Resource Management - work-life balance talks \\
\hline & Human Resource Management - diversity awareness training, sensitivity, mutual respect \\
\hline & Human Resource Management coaches - on people issues as they arise - interpersonal \\
\hline & Human Resource Management communicates - gathers feedback on training reviews \\
\hline & Human Resource Management activity must be integrated to talent management \\
\hline & Human Resource Management is to provide a framework of how best people can be coached, engaged - a tool box for line management \\
\hline \multirow[t]{8}{*}{ Talented employee } & $\begin{array}{l}\text { Talented - are motivated, exceed performance expectations, demonstrate leadership and potential, ambitious, want to grab } \\
\text { opportunities, career-minded, are self-directed }\end{array}$ \\
\hline & Talented must also identify other talents they are responsible for \\
\hline & Be top achievers \\
\hline & Have emotional intelligence, humility and no arrogance \\
\hline & Talent must achieve targets and perform and develop a balance between technical and interpersonal skills \\
\hline & Talent to have good people skills \\
\hline & Work on areas of development, receive coaching and mentoring \\
\hline & Allow others to help in areas needing development \\
\hline
\end{tabular}

TABLE 7: Challenges in talent management.

\begin{tabular}{|c|c|}
\hline $\begin{array}{l}\text { Theme 7: Challenges in talent } \\
\text { management }\end{array}$ & Excerpts from interviews and sources \\
\hline \multirow[t]{17}{*}{ Challenges (general) } & Programme could be defined clearly, as to what it means and how to implement \\
\hline & There are multiple initiatives to develop people but they are not labelled as talent management \\
\hline & $\begin{array}{l}\text { High potential risks - they handle business pressure, long hours, and do stretch projects - they should not be pushed beyond } \\
\text { emotional capacity }\end{array}$ \\
\hline & Managing conflict with team members is an issue to be managed \\
\hline & Favouritism is not Talent Management - process must be fair and consistent \\
\hline & There is subjective evaluation of who is talent \\
\hline & Talent is defined by personal filters \\
\hline & Talent is ability, performance and aspiration - be able to measure that accurately \\
\hline & Defining talent is not achieved \\
\hline & Talent Management is a measure of intensity of what makes a difference between good to great - how do you measure that? \\
\hline & The talent management programmes must be transparent \\
\hline & $\begin{array}{l}\text { The definition of Talent Management is critical in helping clarify why people are on the Talent Management programme (fast track, } \\
\text { accelerated learning, access to executives, having a mentor) }\end{array}$ \\
\hline & The issue of consistency around the talent pool changes \\
\hline & Talented people are not known publicly in the organisation \\
\hline & Talented desire to have public recognition as they work hard \\
\hline & More openness is needed about the criteria for the programme \\
\hline & Team moral \\
\hline
\end{tabular}

Sub-theme: Challenges in talent management

Management commitment and buy in Individuality - take into account people's needs, context, environment, culture and age

Creating a clear policy - expectation and how 
TABLE 7 (Continues...): Challenges in talent management.

\begin{tabular}{|c|c|}
\hline $\begin{array}{l}\text { Theme 7: Challenges in talent } \\
\text { management }\end{array}$ & Excerpts from interviews and sources \\
\hline & $\begin{array}{l}\text { Do not box people } \\
\text { Avoid hype and flavour of the month }\end{array}$ \\
\hline & Executive focus should be on both people and business targets \\
\hline & Development should not be an afterthought - but have a talent mindset in every business activity \\
\hline & Time - executives and managers to track engagement of talented people \\
\hline \multirow[t]{6}{*}{ Financial support } & Paying high remuneration is difficult for business affordability - expensive \\
\hline & Competitor bonuses are hard to compete with for the company (sources) \\
\hline & Line management is not rewarded enough for driving people agenda \\
\hline & Line management is rewarded for business targets, not intangibles \\
\hline & Structure too lean to focus on people issues - people are busy with tight schedules and work programmes \\
\hline & Costs and budgets are an issue in implementing Talent Management \\
\hline \multirow[t]{4}{*}{ Time resource } & Time and availability to counsellors (career and performance) as they are line managers, client facing \\
\hline & Sustainable programme - financial, time, effectiveness, resource availability \\
\hline & Time and availability are an issue in Talent Management \\
\hline & It takes time to conduct career conversations, mentor, and track progress in addition to the roles \\
\hline \multirow[t]{5}{*}{ Capacity } & Selling the employer branding both internally and externally \\
\hline & Independent exit interview to know why talent leaves \\
\hline & Transitioning in a promotion - emotional readiness issue to be resolved by support \\
\hline & Talented may be challenged by their colleagues, social isolation of not being liked \\
\hline & Hard to commit to career growth - economic cycles, change in market conditions \\
\hline \multirow[t]{11}{*}{ Politics } & Human Resource Management value not appreciated \\
\hline & Management not recognising value of Human Resource Management \\
\hline & Human Resource Management to move from administration to value adding \\
\hline & Human Resource Management strategic role is not yet tangible \\
\hline & Human Resource Management to know the business - economics, information technology and finance \\
\hline & Do not put people in boxes and clusters, manage an individual's uniqueness \\
\hline & $\begin{array}{l}\text { Balance of not alienating solid citizens - look after good performers too, and not only focus on high maintenance of the talented as solid } \\
\text { citizens are needed }\end{array}$ \\
\hline & Disclosing who is on a talent management programme is an issue \\
\hline & $\begin{array}{l}\text { Human Resource Management - custodian of Talent Management - often the profession in the organisation is not seen as talent (creates } \\
\text { dissatisfaction) }\end{array}$ \\
\hline & Talent management - only extended to functions which directly influence the bottom line - feelings of discontent could arise \\
\hline & 'Them' and 'us' conflict - those on Talent Management programme \\
\hline \multirow[t]{5}{*}{ Labour dynamics } & Retention is a key issue - young people stay for 2 years, we want 5 years' service \\
\hline & Shortage of African and coloured candidates - they are expensive (diversity) \\
\hline & Retention of diversity candidates - poached by competitors for high pay \\
\hline & Retention - yes people do get disgruntled in the jobs \\
\hline & Not always possible to achieve a career plan \\
\hline
\end{tabular}

TABLE 8: Business case for talent management.

Theme 8: Business case for talent management

\section{Sub-theme: Business case for talent management}

Retention
Business case (general)

Excerpts from interviews and sources

It is not just spending money on TM but an investment - (return)

TM does add value - return may be calculated in performance, customer service, success of the business

Retaining already qualified Chartered Accountants is a challenge - if they leave we lose skills and knowledge

Retention minimises turnover

Talented ensure people supply, no need to replace, retrain and pay recruitment fees

Illustrated a cycle of employee motivation through talent management

Turnover of staff is reduced

Retention is critical to proof against competitor poaching

Retention secures continued and uninterrupted productivity

The retention success saves the company - recruitment fees, time it takes to train the person before they can be productive

Sustainability $10 \%$ of talented are fast-tracked for future executive-ship - retain skill, future leaders, talent pool and pipeline (sources)

Long-term sustainability of the business - talent pipeline and supply

Succession planning and reflect on success

Talented are future leaders and must be future focused, create opportunities for future stability of the company

Talented to create competitive advantage (sources)

Organisations need to spend money on the talented people

Financial

Talent management contributes directly to the bottom line 
TABLE 8 (Continues...): Business case for talent management.

\begin{tabular}{|c|c|}
\hline Theme 8: Business case for talent & Excerpts from interviews and sources \\
\hline & Talented people are high performers and their business performance is measurable on a scorecard \\
\hline & They contribute to financial results, sales targets and profit \\
\hline & Talented contribute to value add and growth \\
\hline \multirow[t]{6}{*}{ Productivity } & $\begin{array}{l}\text { Performance management is aligned to business goals (finance, sales, and customer relations). People are coached, trained to achieve } \\
\text { business results }\end{array}$ \\
\hline & Talent does work for our clients as we sell time, knowledge, service \\
\hline & Talent must improve the company, bring solutions, improve operations, quality and give back by performance \\
\hline & Talented to take ownership of projects (sources) \\
\hline & Outcomes of talent performance and contribution must be obvious \\
\hline & Productivity and high performance \\
\hline \multirow[t]{4}{*}{ Quality work } & Reason for Talent management is to capitalise on knowledge they acquire \\
\hline & A value derived from Talent management must be defined and articulated (A1) \\
\hline & The question is do we have knowledgeable and motivated people? \\
\hline & In retaining talent you can retain your customers and profitability \\
\hline
\end{tabular}

by applying sophisticated measures relating to marketing and communication skills (see Table 9). In other words, talent management needs to be packaged attractively to appeal to the relevant audience.

\section{Career life stages}

The focus of this section (see Table 10) is to assess and determine talent management needs at various career life stages. In other words, what talent management interventions are needed for talent at various career life stages or cycles? This is extremely important as a blanket approach and oneglove-fits-all approach to talent management delivery must be avoided.

\section{Discussion}

The primary aim of the study was to develop a talent management framework for the private sector. The proposed talent management framework (based on constructs brought forward by research participants as well as information from the literature or documents) will be discussed next.

\section{The proposed talent management framework}

The proposed talent management framework is discussed in Figure 1.

\section{The framework consists of the following:}

- planning (consists of external environmental analysis, business strategy, talent strategy and talent success profile)

- dimensions of talent management (consists of attraction, sourcing and recruitment, deployment and transition, grow and develop, performance management, talent reviews, rewarding and recognition, engage and retain)

- implementation with reference to career stages (early career: Generation Y; mid-career: Generation X; late career: baby boomers)
- best practise enablers (consists of talent management communication tactics, internal organisational practices and information technology for talent management)

- role players (focuses on the responsibilities of human resources, talented candidates and leadership)

- evaluation of effectiveness (focuses on evaluating how talent management is being implemented in the organisation).

\section{Planning}

According to Robbins and Coulter (2010), planning involves the process of defining goals, establishing a strategy for achieving those goals and developing the plans to coordinate and integrate the activities:

- External environmental analysis: The organisation needs to be knowledgeable about external dynamics to allow change and adaption in order to stay abreast and survive in the dynamic and complex environment. Therefore, variables such as competition, business trends, markets and customer needs need to be continuously analysed.

- Business strategy: Once the organisation has analysed all the external variables, it can begin to devise an informed business strategy. This strategy defines the purpose and reason for being of the organisation, often expressed in the form of a vision, mission and values.

Talent strategy: The talent strategy only emerges from a firm knowledge of the overall business strategy, to ensure alignment. Where the organisation has articulated which markets, products and services they need to pursue, it is only then that a decision can be made about the type of skills, capabilities and core competencies required in order to drive strategy.

Talent success profile: The success profile provides a blueprint of the makeup and characteristics of talent in attitude, behaviour, actions, achievements and capability. 
TABLE 9: Optimising talent management Theme 9: Optimising talent management Optimising talent management (general)

Sub-theme: Optimising talent management Employer branding

Excerpts from interviews
Decide on what the business needs and future plans for talent
By proper needs assessment for Talent Management programme the solution can be tailor-made
Design and develop talent strategy
Proper forecasting of talent needs and requirements
Clear criteria on talent review process
Create credibility through criteria of the process
Ensure that there is diversity in the programme
Do not put people in a box
Work hard on ensuring career advancement and good management to retain talent
Paying market-related salaries is critical
Psychometric assessment may be utilised to provide accurate identification of potential
Social networks are critical - to discuss current business problems and topics
Sharing of work/business learning is critical
Having guest speakers to address the talented on a specific topic

Having guest speakers to address the talented on a specific topic
Employee value proposition

Sourcing and attraction
Improve employer branding through recruiters

Keep employer branding internally and externally - attraction issue

Recruiters must sell the brand correctly

Branding is critical both internally and externally - what people have

Talent as brand ambassadors must advertise both internally and externally (role models)

Improve internal firm's branding

Employer branding must be consistent - internally and externally

Investing in bursary and educational development initiatives to develop African Chartered Accountants - talent pool creation

We need to fix value proposition when recruiting

Not sell what we think person wants to hear - value proposition

Value proposition - know what the person wants, status, money, achievement or values

Define culture - Employee value proposition purposes, people know what to look for

Recruiting - assessments are used - personality and cognitive

Recruiting - by internal employee referrals - give bonus for successful recruiting

Diversity and inclusiveness is critical

Create and attract talent pools wanting to live the vision and are passionate

Strategic leadership is required in attracting talent

Too modest in marketing our organisation - need to improve image

Branding - to sell culture - people-centric, nice people, family oriented, not arrogant, not snotty, tough managers but nice. We undersell our brand

Selling and marketing - we miss out if we do not sell our people-oriented culture, interaction. Other companies are arrogant, stuck up and difficult

Long-term liaison and relationship building with talent

Use feedback on success of development programmes

When recruiting be attentive to individual needs

People are not a number - humanness in dealing with people is critical

Recognise people are different

Treat talented as you would treat a client

Use a customer-centric model in dealing with employees

Treat employees as you would customers

Climate assessments

People leave the organisation and then come back (good environment)

Retention risk assessment by conversation with coaches

Assess engagement - energy and drive to look forward to the job

Engagement - emotional connectedness to the job

Engagement - intention to stay - love the job, peers, company, pay

Continuous improvement
Create rich pools of talent

Study best practices

Talent Management must be measured, implemented and defined

\section{Dimensions of talent management}

Once the organisation decides on what talent strategies they are going to pursue, it becomes even more critical to develop action plans for implementation purposes. The process entails how activities will be carried out to support the plans.

Johnson et al. (2011) view implementation as a plan to translate the formulated strategy into workable strategies and tactics filtering down through the organisation. Robbins and Coulter (2010) indicated that implementation includes conveying the decisions and plans to those affected by it and getting their commitment to carry it out:

- Attraction: The ultimate aim of the attraction activity is to interest the external candidates and motivate them to join the organisation, while creating a long-term intention to retain and encourage their intention to 
stay with the organisation. The same rigour that is applied to marketing and selling products and services must be applied in marketing and advertising the employer brand and value proposition for current and future employees. Social media may be utilised as a tool to communicate, do the marketing and build the employer branding concept (Robbins \& Coulter, 2010).

- Sourcing and recruitment: There is a big opportunity for companies to use the internet and social media for sourcing talent and managing the recruitment processes of job profiling, advertising of vacancies and managing of job applications. Technology tools are now readily available to remove and eliminate tedious, old and lengthy paper-driven processes of recruitment (Robbins \& Coulter, 2010).

- Deployment and transition: The purpose of this dimension is to ensure that the new recruits become familiar with the new organisation where they are employed quickly, through a socialisation process. Furthermore, the employees can effectively transition into the new role whether it is an internal transfer, a new recruit or a recent promotion. At this early stage, the new recruit can be strongly influenced to form a positive image and good impressions about the organisation. It is also recommended that a social mentor be appointed for the new recruit in order to assist with manoeuvering through the organisation in dealing with offbeat, difficult people, politics and sociocultural nuances (Johnson et al., 2011).

- Performance management: Performance management is a vital part of the process of development and the identification of talent. It is a fully participative process in goal and objective setting in alignment with the interpretation of the business strategy. The communication and giving of feedback constitute the leading ingredients of performance management, which leads to continuous improvement in the organisation. This participative communication is between the employee and the immediate supervisor or line manager (Caplan, 2011).

- Grow and develop: Training is beneficial only when it is linked to the overall business goals and it supports the achievement of business objectives like improving quality, increasing productivity and improving customer service; otherwise, training becomes an expensive hobby for the organisation. Line management, in collaboration with human resource or talent management specialists, may design learning and development programmes 


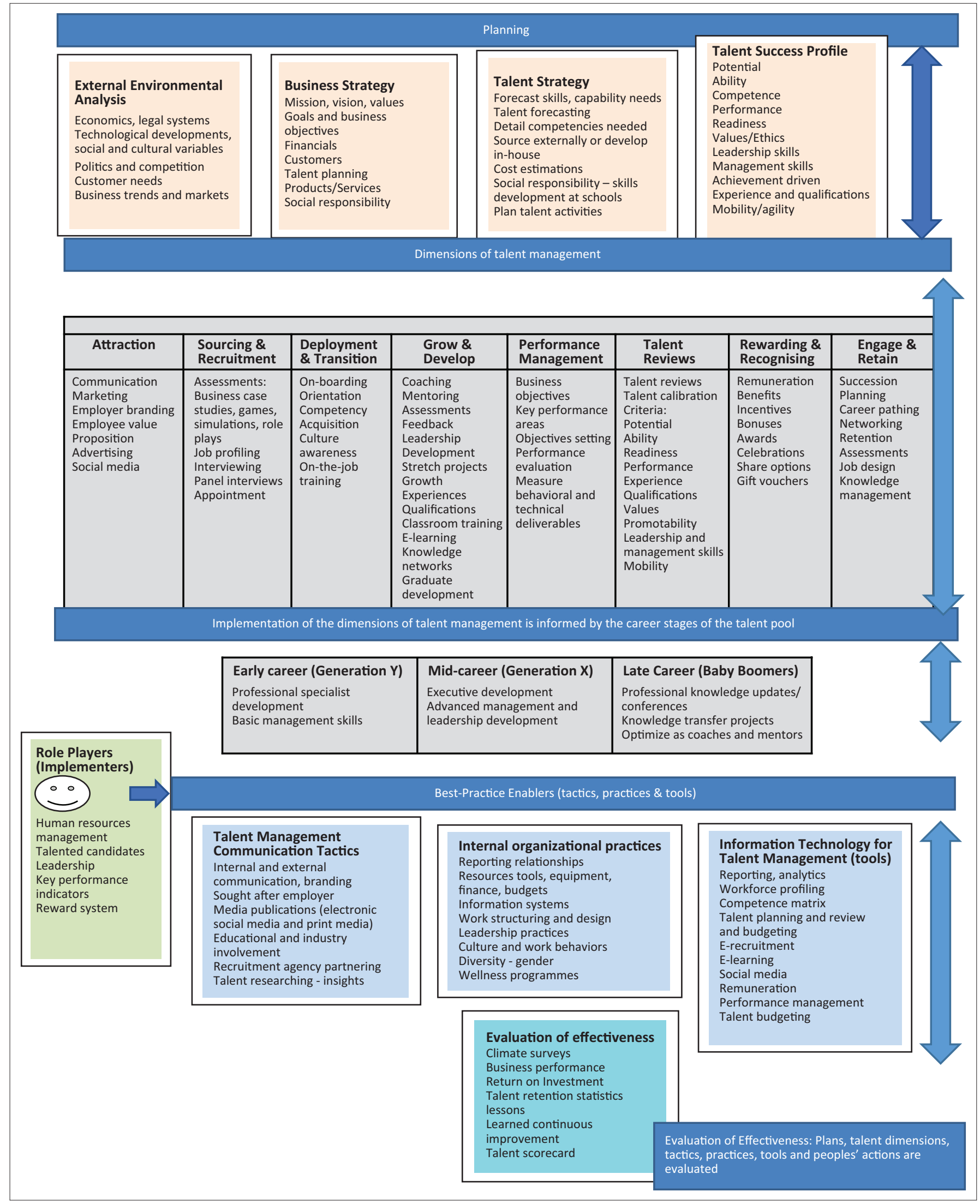

FIGURE 1: A talent management framework for the private sector.

which address the knowledge and skills needed currently and in the future by the organisation, for example, graduate development programmes (Li \& Bryan, 2010).
- Rewarding and recognising: Importantly, remuneration strategies have to be tied to overall business objectives. The business rightly pushes for high performance in 
areas of financial performance, increased sales, costsaving initiatives and customer satisfaction. When the objectives and targets are achieved, the high performers who contributed to the success have to be rewarded and recognised according to their value add (Caplan, 2011).

- Engage and retain: Successful retention of the employees is really determined by how engaged the employees are with the job, role and the overall organisational activities. In order to determine factors which enhance employee engagement, the employer needs to run an assessment and get input from the employees about the matter. A blend of financial rewards, with creation of a sense of purpose and meaning about the job, giving direction, communication and fair human resources practices, improves engagement substantially. Career pathing, succession planning and management are important in improving both retention and employee engagement (Li \& Bryan, 2010).

- Talent reviews: Talent reviews usually constitute a meeting between human resources and senior management to discuss all matters relating to talent management. The conversations are structured around overall high performance and high potential (capability to grow into a senior role) of individuals in the talent pool. Furthermore, individuals admitted to the talent pool must have relevant experience, qualifications, outstanding performance track record and demonstrable capability and potential to be promoted to a senior or highly critical role within a specified timeframe (Caplan, 2011).

\section{Implementation of the dimensions of talent management}

In implementing talent management dimensions across the organisations in various functions, managers and human resources need to be aware of the needs and characteristics of specific talent pools in relation to their career life stages:

- Early career stages: Focus on intensive and structures learning interventions to support professional specialist development and growth. Job design and structuring of work should allow working in highly interactive teams and intensive use of new technology.

- Mid-career stage: Relevant leadership development interventions should be provided focusing on executive development, advanced management and leadership development programmes to support succession and career path planning. Create meaningful and purposedriven work and careers.

- Late career stage: Provide counselling to help employees to prepare for retirement. Reduce the involvement in projects requiring an investment in long hours.

\section{Best practice enablers}

In order to improve the implementation of talent management projects, the following can be looked at:

- Talent management communication tactics: It is important to communicate the purpose of the talent management programme to all the stakeholders clearly when making it known. This will create openness and acceptance. Ways of communication can include company magazines, updates on intranet, posters, video clips, communication forums, meetings, social media, suggestion boxes and focus groups.

- Internal organisational practices: Efforts should be made to develop a people-oriented culture which focuses on individual success, and where technology is integrated into the work processes. Diversity should be valued and innovation and continuous improvement should be welcomed. Wellness programmes should be implemented and financial resources should be made available to successfully initiate and implement talent management programmes. Reporting relationships must be managed professionally, ethically and fairly. Much responsibility is placed on the direct supervisor to create healthy ways of relating to employees. Talent management information systems are critical in supporting the alignment, coordination and integration of the entire talent management process from start to end. The use of the system may vary from data input, electronic filing and information processing to providing management reporting and data analytics.

\section{Role players}

Role players are the key stakeholders in the business who are responsible for the development, planning, implementation and improvement of talent management projects in the organisation:

- Management: Line managers are directly responsible for identifying, selecting and recommending the high potential and high performing talented employees in their teams to become part of the official talent management pool.

- Talent pools: Talented employees have an active role to play in order to ensure that they have acquired the necessary skills, knowledge and experience to assist their career growth aspirations.

- Leadership: Organisational leaders are solely responsible for developing strategic initiatives which drive the business, and ensure that it is cascaded to the implementers. These strategic initiatives include giving direction to human resource leadership in aligning talent management strategies and tactics with that of the business.

- Human resources: Human resources is responsible for developing the talent strategy in line with the business strategy, as well as guiding management and the leadership team in applying the tools, systems and processes of talent management.

\section{Evaluation of the effectiveness of talent management}

Talent management needs to be evaluated against a set of criteria in order to track success as well as areas needing improvements. Measures for testing the effectiveness of talent management are through monitoring talent retention statistics and acquiring lessons or narrations for the state of statistics. The evaluation may be used as a basis for continuous improvement. 


\section{Practical implications}

Role players are the key stakeholders in the business who are responsible for the development, planning, implementation and improvement of talent management projects in the organisation. It is therefore critical to set key performance indicators for all the role players which pertain to talent management activities, and set reward systems which encourage strong performance.

\section{Management}

Line managers are directly responsible for identifying, selecting and recommending the high potential and high performing talented employees in their teams to become part of the official talent management pool. They have a much greater responsibility in the recruitment, supporting, onboarding and induction to new roles, managing performance and identification of learning and development needs. Retention of employees is highly influenced by the quality of direct line management, as employees interact frequently with the direct line manager. To the employee, the immediate line manager creates the impressions about the company culture, values and practices. Line management needs to assume responsibility and accountability for the outcomes of managing talent in their respective units and departments. Career and succession planning, coaching, communication and feedback to the employee are to be carried out continuously by the direct manager with the employee in a professional, open and honest manner.

\section{Talent pools}

Talented employees have an active role to play in order to ensure that they acquire necessary skills, knowledge and experience to assist their career growth aspirations. They have to be agile, flexible and mobile in their approaches to work and conduct. Furthermore, talented employees need to partake in stretch projects, management and leadership development programmes and must travel to some extent. Continued high performance is important as it will ensure them a place in the talent pool, as well as career growth.

\section{Leadership}

Organisational leaders are solely responsible for developing strategic initiatives which drive the business, and ensure that it is cascaded to the implementers. These strategic initiatives include giving direction to human resource leadership in aligning talent management strategies and tactics with that of the business. Furthermore, the leadership team needs to hold management accountable for the delivery of talent management initiatives. Leadership has to ensure that talent management strategies are effective, support the business objectives and add value to the business imperatives. If the leadership is not involved actively in being a sponsor of talent management initiatives, the talent management practices will not take priority in the organisation - it will just be one of those human resources activities.

\section{Human resource}

The senior human resource executive (from the Human Resource Management Department) is responsible for developing the talent strategy in line with the business strategy, as well as guiding management and the leadership team in applying the tools, systems and processes of talent management. Human resources executives will most likely lead and facilitate the talent review meetings and conduct audits in the organisation to drive the implementation of talent management dimensions and tactical plans. It is a human resource deliverable to procure assessment tools and information systems, to monitor culture, to improve the employer brand and to champion talent-centric practices in the organisation. Talent-centric practices are reward programmes, the creation of a healthy work environment, learning and growth initiatives, and so on (Caplan, 2011).

Organisations need to go as far as allocating talent management activities, tasks and deliverables to the performance management process in the form of key performance indicators. When the talent management key performance indicators are met, the role players must be rewarded to support and reinforce commitment and implementation.

\section{Limitations of the study}

The limitations of the study are mainly because of the purposive non-probability sampling method used. Consequently, the sampling method does not allow for generalisation of the findings to the general population (Thomas, 2006).

Furthermore, it would have been preferred to include a much bigger and broader sample (participants) and more cases (companies in the private sector), but this was not possible. The study is not rendered invalid and insufficient because of the elements stated above. With the few participants and two cases consulted in the study, the researcher has managed to collect comprehensive and detailed data, referred to as 'thick' descriptions. During the interviews and the data analysis process, the researcher realised and confirmed data saturation and sufficiency, as concepts, themes and patterns were repeated by the participants.

\section{Recommendations for future research}

Anecdotally, it is known that talent management is a valuable best practice to have in an organisation. It would be of substantial value to have a set, defined, specific and consistent formulae to calculate the real economic value of investing in talent management activities quantitatively. Often, the investment in certain assets or finances spent in business activities is justified by possible financial and economic benefits that might be realised, and these financial returns are easy to track. Therefore, the practice of talent management will benefit from the ability to report on the actual economic value realised. This capability will improve buy in and a willingness to invest in high-quality talent management initiatives and resources. 


\section{Conclusion}

In conclusion, the dimensions of talent management were identified and developed. The delivered talent management framework will guide and support the elevation of talent management practices in organisations in the private sector. The framework is comprehensive enough to cover all key and core dimensions of talent management practice. Ultimately, the framework is developed in such a way that it can lead to best practice.

\section{Acknowledgements Competing interests}

The authors declare that they have no financial or personal relationships that may have inappropriately influenced them in writing this article.

\section{Authors' contributions}

E.S.v.Z. was responsible for the overall conceptualisation and co-writing of the article, while R.B.M. executed the study and helped with the writing of the article. J.R. was responsible for co-writing the article and contributed to the list of references.

\section{References}

Arris, A.A., Cascio, W.F., \& Paauwe, J. (2013). Talent management: Current theories and future directions. Journal of World Business, 49, 173-179. https://doi. org/10.1016/j.jwb.2013.11.001

Ashton, C., \& Morton, L. (2005). Managing talent for competitive advantage: Taking a systematic approach of talent management. Strategic Human Resource Review, 4(5), 28-31. https://doi.org/10.1108/14754390580000819

Bell, A. (2005). The employee value proposition redefined. Strategic HR Review, 4(4), 1-3. https://doi.org/10.1108/14754390580000792

Bersin, J. (2006). Talent management: What is it? Why now? Oakland, CA: Bersin \& Associates.

Bondas, M. (2006). Paths to nursing leadership. Journal of Nursing Management, 14(1), 332-339.

Boshard, D., \& Louw, A. (2011). Talent - Trends impacting its availability and what you business should do about it. In I. Boninelli \& T. Meyer (Eds.), Human capital trends: Building a sustainable organisation (pp. 44-58). Randburg: Knowres Publishing.

Botma, Y., Greeff, M., Mulaudzi, F.M., \& Wright, S.C.D. (2010). Research in health sciences. Cape Town: Heinemann.

Bromley, D.B. (1990). Academic contributions to psychological counselling: I. A philosophy of science for the study of individual cases. Counselling Psychology Quarterly, 3(3), 299-307. https://doi.org/10.1080/09515079008254261

Caplan, J. (2011). The value of talent: Promoting talent management across the organisation. London: Kogan Page.

Charmaz, K. (2000). Grounded theory: Objectivist and constructivist methods. In N.K. Denzin \& Y.S. Lincoln (Eds.), Handbook of qualitative research (pp. 509-535). Thousand Oaks, CA: Sage.

Charmaz, K. (2006). Constructing grounded theory: A practical guide to through qualitative analysis. London: Sage.

Chikumbi, C. (2011). An investigation of talent management and staff retention at the Bank of Zambia. Unpublished MBA dissertation, Nelson Mandela Metropolitan University, Port Elizabeth.

Church, A.H., Rotolo, C.T., Ginther, N.M., \& Levine, R. (2015). How are companies designing and managing their high potential programmes? Psychology, 67, 17-47.

Collings, D.G. (2014). Towards mature talent management. Human Resources Development Quarterly, 25, 301-312. https://doi.org/10.1002/hrdq.21198

Collings, D.G. \& Mellahi, K. (2009). Strategic talent management: A review and research agenda. Human Resource Management Review, 19(4), 304-313. https:// doi.org/10.1016/j.hrmr.2009.04.001

Corporate Research Foundation. (2011). Best employers: South Africa 2011/12. (12th edn.). Cape Town: CRF Institute.

Cron, W.L., \& Slocum, J.W. (1989). The career stages on salespeople's job attitudes, work perceptions, and performance. Journal of Marketing Research, 23(2), 119-129. https://doi.org/10.2307/3151659

DeLong, D., \& Trautman, S. (2011). The executive guide to high impact talent management: Powerful tools for leveraging a changing workforce. New York: McGraw-Hill.
Effron, M., \& Ort, M. (2010). One page talent management: Eliminating complexity, adding value. Boston, MA: Harvard Business Press.

Egerova, D. (2014). Talent management: Towards new perspectives. Problems of Management in the 21st Century, 9(2), 114-128.

Festing, M., \& Shafer, L. (2014). Generational challenges to talent management Journal of World Business, 49, 262-271. https://doi.org/10.1016/j.jwb.2013. 11.010

Gatherer, J., \& Craig, D. (2010). I am talent: A comprehensive guide to optimise your potential and achieve your personal and career aspirations. Randburg: Knowres Publishing.

Greene, J. (2010). Case study: Southern company. In M. Goldsmith \& L. Carter (Eds.), Best practice in talent management: How the world's leading corporations manage, develop, and retain top talent (pp. 241-256). San Francisco, CA: Pfeiffer.

Haid, M., Sims, J., Schroeder-Saulnier, D. \& Wang, H. (2010). Organisationa effectiveness: Discovering how it happens. Leadership insights incorporated. Retrieved August 15, 2013, from http://www.right.com

Hatum, A. (2010). Next generation talent management: Talent management to survive turmoil. Hampshire: McMillan.

Hess, N., \& Jepsen, D.M. (2009). Career stage and generational differences in psychological contracts. Career Development International, 14(3), 261-283. https://doi.org/10.1108/13620430910966433

Johnson, G., Scholes, K., \& Whittington, R. (2011). Exploring corporate strategy: Text and cases. (9th edn.). London: Prentice Hall Financial Times.

Johnson, P. (2004). Analytic induction. In C. Cassell \& G. Symon (Eds.), Essential guide to qualitative methods in organisational research (pp. 165-179). London: Sage.

Lacey, A., \& Luff, D. (2009). Qualitative data analyses. The National Institute of Health Research. University of Nottingham. Retrieved September 16, 2012, from http:// www.rds-eastlands.nirh.ac.uk

Leedy, P.D., \& Ormrod, J.E. (2010). Practical research: Planning and design. (9th edn.) Boston, MA: Pearson Education International.

Li, X., \& Bryan, L. (2010). On becoming an employer of choice: Gauging employee satisfaction through climateQUAL. Library Trends, 58(2), 256-268.

Marshall, C., \& Rossman, G. (1995). Designing qualitative research. Thousand Oaks, CA: Sage.

Meyer, T. (2005). Talent management. Fasset Leadership SA, 1-12.

Meyers, M.C., \& Van Woerkom, M. (2013). The influence of underlying philosophies on talent management: Theory, implications for practice and research agenda. Journal of World Business, 49, 192-2013. https://doi.org/10.1016/j.jwb.2013. 11.003

Moore, T.S., Lapan, S.D., \& Quartaroli, M.T. (2012). Case study research. In S.D. Lapan, M.T. Quataroli, \& F.J. Riemer (Eds.). Qualitative Research: An introduction to methods and design (pp. 231-251). San Francisco, CA: Jossey Bass.

Nijs, G., Gallardo-Gallardo, G., Dries, S., \& Sels, M. (2014). What is the meaning of talent in the world of work? Human Resource Management Review, 23, 290-300.

Ntonga, S. (2007). The impact of talent management practices on business performance. Unpublished MBA dissertation, University of Pretoria, Pretoria, South Africa.

Odierno, R.T. (2015). Leader development and talent management. Military Review, 9-14.

Pellant, A. (2011). Linking culture and talent management. In L.A. Berger \& D.R. Berger (Eds.), Talent management handbook: Creating a sustainable competitive advantage by selecting, developing, and promoting the best people (pp. 315-320). New York: McGraw Hill.

Powell, M., \& Lubitsh, G. (2007). Courage in the face of extraordinary talent: Why talent management has become a leadership issue. Strategic Human Resource Review, 6(5), 24-27. https://doi.org/10.1108/14754390980000998

Prinsloo, L. (2012). Talent management and psychological contract. Unpublished MCom dissertation, University of Pretoria, Pretoria, South Africa.

Quandt, S.A., McDonald, J., Bell, R.A., \& Arcury, T.A. (1999). Aging research in multiethnic rural communities: Gaining entrée through community involvement. Journal of Cross- Cultural Gerontology, 14(1), 113-130. https://doi.org/10.1023/ A:1006625029655

Robbins, S.P., \& Coulter, M. (2010). Management. (11th edn.). Upper Saddle River NJ: Prentice-Hall.

Rose, A. (2007). Ethics in human resources management. New York: McGraw-Hill.

Silzer, R., \& Dowell, B.E. (2009). Strategy driven talent management: A leadership imperative. New York: Wiley.

Smelser, N.J., \& Baltes, P.B. (2001). Analytic induction. In N.J. Smelser \& P.B. Baltes (eds.). International encyclopaedia of the social and behavioural sciences. Amsterdam: Elsevier.

The Chartered Institute of Personnel and Development (CIPD). (2006). Change agenda: Talent management - Understanding the dimensions. London: CIPD.

Thomas, D.R. (2006). A general inductive approach to analysis qualitative evaluation data. American Journal of Evaluation, 27(20), 237-246. https://doi.org/10.1177/ 1098214005283748

Tucker, E., \& Williams, R. (2011). The intersection of talent management and engagement. The international resource for benchmarks and best practices. Houston, TX: APQC International.

Yin, R.K. (2011). Qualitative research from start to finish. New York: The Guildford Press. 